JOURNAL OF SECURITY AND SUSTAINABILITY ISSUES

ISSN 2029-7017 print/ISSN 2029-7025 online

2019 September Volume 9 Number 1

http://doi.org/10.9770/jssi.2019.9.1(26)

Scopus

\title{
INFLUENCE OF THE MARKET OF BUSINESS INTELLECTUAL SERVICES ON THE INNOVATION SAFETY OF EU COUNTRIES
}

\author{
Svitlana Filyppova $^{1}$, Valery Okulich-Kazarin ${ }^{2}$, Olha Kibik $^{3}$, Grygoriy Shamborovskyi ${ }^{4}$, Svitlana Cherkasova ${ }^{5}$ \\ 1,5* Odessa National Polytechnic University, Shevchenko avenue, 1, Odesa, 65044, Ukraine \\ ${ }^{2}$ Pedagogical University of Cracow, Podchorazych str., 2, Krakow, 30-084, Poland \\ ${ }^{3}$ National University “Odessa Law Academy”, Fontanskaya str., 23 Odesa, 65009, Ukraine \\ ${ }^{4}$ Ivan Franko National University of Lviv, 1, Universytetska St., Lviv, 79000, Ukraine \\ E-mail: ${ }^{5 *}$ koaduep@gmail.com
}

Received 10 December 2018; accepted 16 June 2019; published 30 September 2019

\begin{abstract}
This paper reveals the specifics of production, promotion and resource support of business intellcctual services at the world market and market of EU countries. It was proved that an important aspect of the production of intellectual services is the process of joint production, where producer and consumer are trusted partners. The features of formation of demand in the market of business intellectual services, subjects of which are mostly innovation-active economy entities, were described, and the influence of this market on the innovation safety of countries was determined. The characteristics of a consumer of business intellectual services was performed taking into account features of national markets and safety of their functioning.
\end{abstract}

Keywords: innovation safety of countries; areas of services; business intellcctual services; economic sectors of EU countries; consumers; export and import of commercial services

Reference to this paper should be made as follows: Filyppova, S.; Okulich-Kazarin, V.; Kibik, O.; Grygoriy Shamborovskyi, G., Cherkasova, S. 2019. Influence of the market of business intellectual services on the innovation safety of EU countries, Journal of Security and Sustainability Issues 9(1): 347-360. http://doi.org/10.9770/jssi.2019.9.1(26)

JEL Classifications: F19, F43, L86

\section{Introduction}

The role of the service sector in the global economic system as a whole, and the sectors of intellectual services, in particular, have a rapid growth dynamics. So, EU countries produce a significant share of value added in this sector, which makes up of $20 \%$ per year in average. The most common type of intelligent services is the socalled business services, namely: consulting, financial, legal, research, and information (Bonditti et al., 2017). However, the significance of the sector of intellectual services is determined not only and not so much by the quantitative leaps as by the qualitative ones that it brings to other sectors of the world economy, but by the provision of innovative safety of countries and their associations.

So, the relevance of the topic of scientific research, on the one hand, is due to the formation of an growing tendency of increase of the role of intellectual services in the global economy as a key factor of economic growth, high activity of companies in the generation, production and promotion of intellectual services, and, on the other hand, increase in the level of intellectual threats through the mass and ease of transferring intellectual capital across the borders of countries (Drobyazko S., 2017). In addition, there is a fragmentation of studies of features of the market for business intelligence services in the leading countries of the world (including in such an integration union as the EU), the lack of appropriate scientific and methodological approaches, taking into 
account the features of their national markets, and understanding the importance of the factor of innovation and intellectual security.

\section{Literature Survey}

The significant contribution to the development of the theory of intellectual services and aspects of national innovation development is made by papers of such researches as (Abrhám, Lžicar, 2018; Chaffey, Ellis-Chadwick, 2012; Hunt, 2000; Kirshner, 2013; Rogers, 2003; Standler, 2014; Thompson, et. al., 2015; Sagiyeva et al., 2018; Girdzijauskaite et al., 2019).

In the work of these authors, certain issues of the specifics of the sector of intellectual services, formation of a large-scale world-wide market of intellectual services, functioning of companies in the market of intellectual services, connection of the activity of the market of intellectual services with economic growth and innovative safety in the world economy have a tendency to conceptual comprehension (Drobyazko S., et al., 2019).

The purpose of the study is to analyze the leading trends in the creation and promotion of business intellectual services in the world market, based on the research of the market of business intellectual services in the EU countries, and determination of the level of influence of these markets on innovation safety.

\section{Methods}

The global trend of the evolution of a developed market economy is an increase in the share of services in total world production and GDP of countries. In the last third of the twentieth century, one of the main trends of economic development is evident - the advancing growth of the services sector in comparison with the sectors of material production and expansion of its economic positions. However, the role of the sector of services in the modern economy is not only related to its predominance in the structure of the world economy (Senan, 2018). Today, key factors of economic growth are formed (scientific and technical knowledge, non-material forms of accumulation, information technologies, etc.) in the service sector.

The consumption process in the business intellectual sector is different from the standard service consumption process, which in turn significantly affects demand. According to the traditional theory of demand, the consumer is able to use any quantity of goods purchased (Dźwigoł et al., 2019).

In turn, the consumer's ability to adapt intellectual services becomes a constraining factor for the sector of business intellectual services, According to the standard economic model, demand for goods is formed under the influence of the needs that arise in the consumer. There is other situation in the sector of business intellectual sector, the fact that the consumer has a need does not yet make him a full-fledged representative of demand, which embodies both desire and opportunity (Solomon et al., 2016). Ability to perceive strongly limits the possibility of full consumption. The demand in the market for business intellectual services is formed by three factors: "need", "paying capacity" and "ability to perceive".

Another feature of demand for business intellectual services is that demand is segmented according to consumer experience. Getting the experience of using intellectual services does not depend on how often the consumer uses the same service, but on the heterogeneity of the consumed services (Vo, et al., 2017).

\section{Results}

We will conduct an analytical study of the state of the world market of intellectual services. Deep scientific, technical, structural and other changes are of great importance in the service sector itself, they are those changes that increase their contribution to the development of the world economy, which create the necessary preconditions for the development of scientific and technological progress. Fig. 1 shows the share of services in GDP, employment and export volumes by region (world, developed countries and developing countries). 


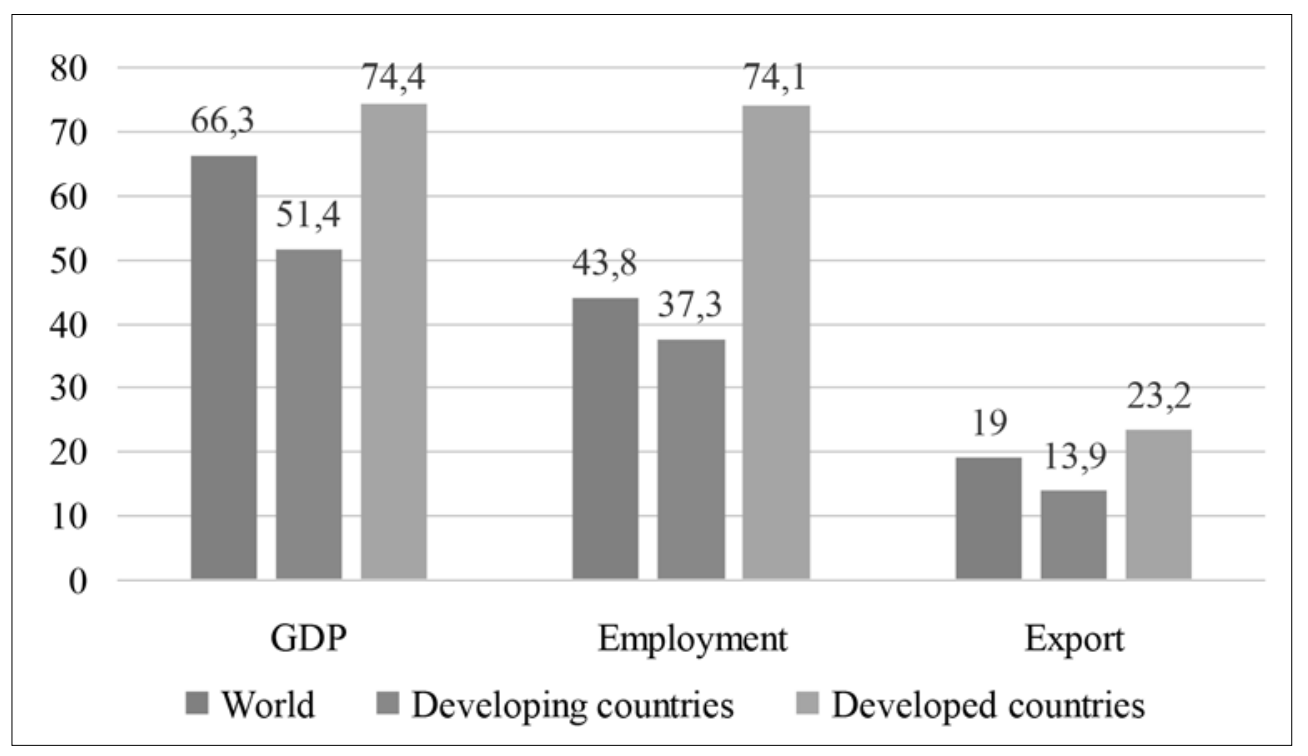

Fig. 1. Share of services in the gross domestic product, employment and total exports in $2018, \%$

Source: Developed by the authors according to the source (World trade statistical review, 2018)

According to expert estimates, about $70 \%$ of the total world output is due to all types of services, with the most dynamic growing sector being international trade in services. The degree of development of the service sector becomes a leading criterion of the development of world society. For large countries, the foreign trade turnover in services is hundreds of billions of dollars (Leese, \& Wittendorp, 2017; Makedon, (2018)).

The international trade in services is the most dynamic sector of international trade. An analysis of the dynamics and composition of world trade in services shows that among the three main groups - transport services, tourism, other commercial services - the group of other commercial services is distinguished by dynamical growth. Between 2006 and 2018, the share of exports of other commercial services increased from 45\% to 54\%, the share of tourist services decreased by $6 \%$ and amounted to $26 \%$, the share of transport services decreased by $2 \%$ and amounted to $21 \%$. The share of imports of other commercial services has increased from $41 \%$ to $48 \%$, the share of tourist services has decreased from 30 to $24 \%$, and the share of transport services has decreased from $29 \%$ to $28 \%$ (Table. 1) (World trade statistical review, 2018).

Table 1. World Trade in Commercial Services, 2006-2018

\begin{tabular}{|c|c|c|c|c|c|c|}
\hline \multirow{2}{*}{ Types of commercial services } & \multicolumn{2}{|c|}{$\begin{array}{c}\text { World trade in commercial } \\
\text { services, 2018, billion dollars. }\end{array}$} & \multicolumn{2}{|c|}{ Share, 2018,\% } & \multicolumn{2}{c|}{ Share, 2006,\% } \\
\cline { 2 - 7 } & Export & Import & Export & Import & Export & Import \\
\hline Transport services & 890 & 1145 & 21 & 28 & 23 & 29 \\
\hline Tourist services & 1110 & 995 & 26 & 24 & 32 & 30 \\
\hline Other types of business services & 2345 & 1965 & 54 & 48 & 45 & 41 \\
\hline Total & 4345 & 4105 & 100 & 100 & 100 & 100 \\
\hline
\end{tabular}

Source: Developed by the authors according to the source (World trade statistical review, 2018)

The average annual increase in operations included in other commercial services exceeds the corresponding indicator for export of transport and tourist services.

The world trade in commercial services in 2018 amounted to 2,345 billion US dollars. Positions of types of services were distributed as follows: "Other commercial services" include financial services (13\%), insurance services (4\%), royalties and licensing payments (12\%), computer and information services (11\%), construction 
$(5 \%)$, telecommunication services $(5 \%)$, personal, recreational, and cultural services $(2 \%)$. The share of other types of business services is $48 \%$ of the total world trade in commercial services (Fig. 2).

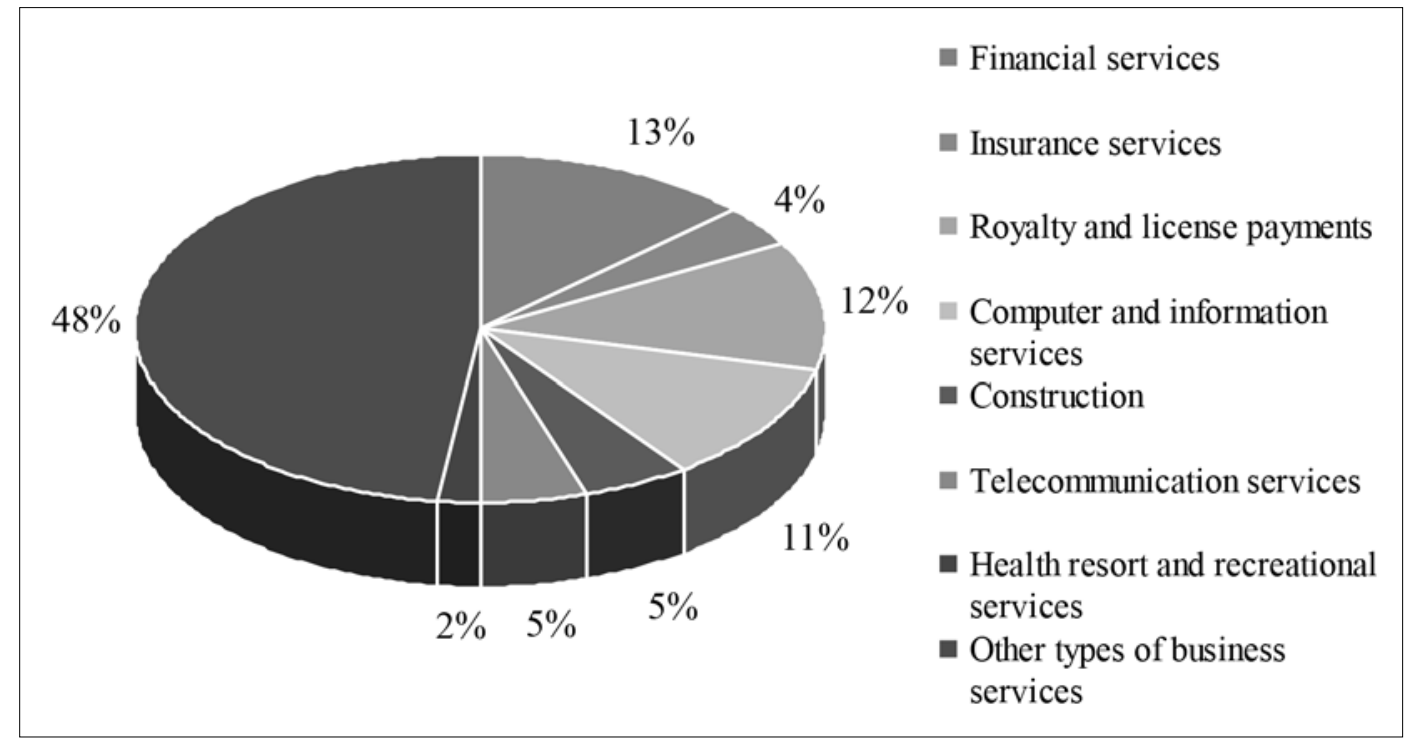

Fig. 2. Specific structure of world exports of other commercial services in $2018, \%$

Source: Developed by the authors according to the source (Global Economic Prospects (2019)

The sector composition of business services is substantially complicated by the association of contentually alike services, which is dictated by the logic of business. The regional structure of world exports of other commercial services shows the largest share of the EU countries in all types of services, other than construction, royalties and license fees, with the leading Asian and North American countries, respectively. The share of regions in world exports of other commercial services is presented in Fig. 3.

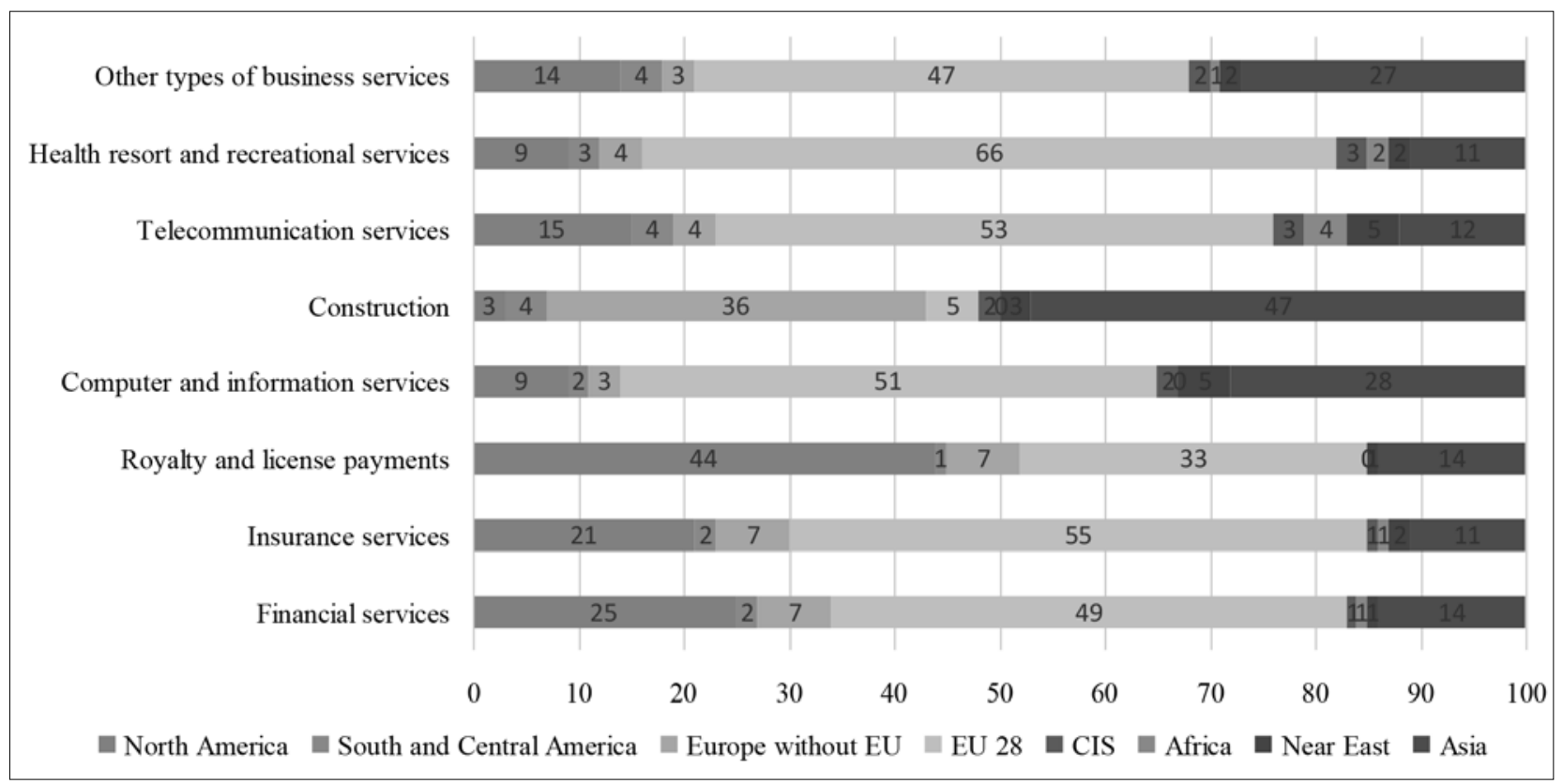

Fig. 3. Share of regions in world exports of other commercial services from industries in $2018, \%$

Source: Developed by the authors according to the source (International Trade Statistics Yearbook)

The regional structure of world exports of other commercial services in value terms is presented in Fig. 4. 


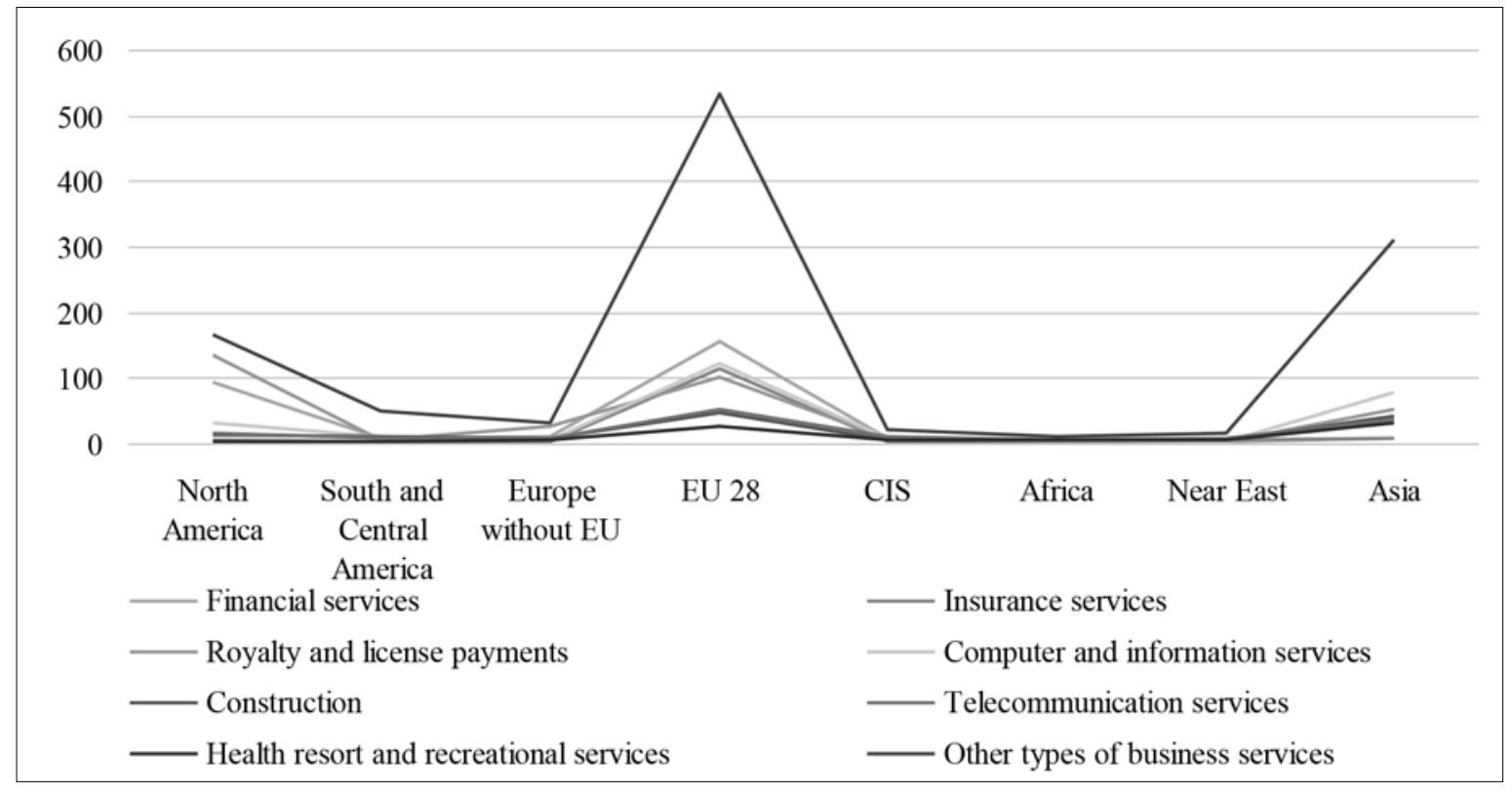

Fig. 4. Exports of other commercial services from the sectors of the world economy in 2018, billion dollars.

Source: Developed by the authors according to the source (International Trade Statistics Yearbook)

The main exporters of other business services are EU countries (more than 50\%), USA (12.5\%), China (6.2\%), and Japan (4.8\%). The main exporters of other business services are EU countries (more than 60\%), USA $(12.5 \%)$, China (10\%), and Japan (6\%). Also, developing countries: like India, Hong Kong and Singapore, show high performance in trade in business services.

The fastest growth demonstrates the trade in computer and information services, insurance services, telecommunications, and other business services (Fig. 5).

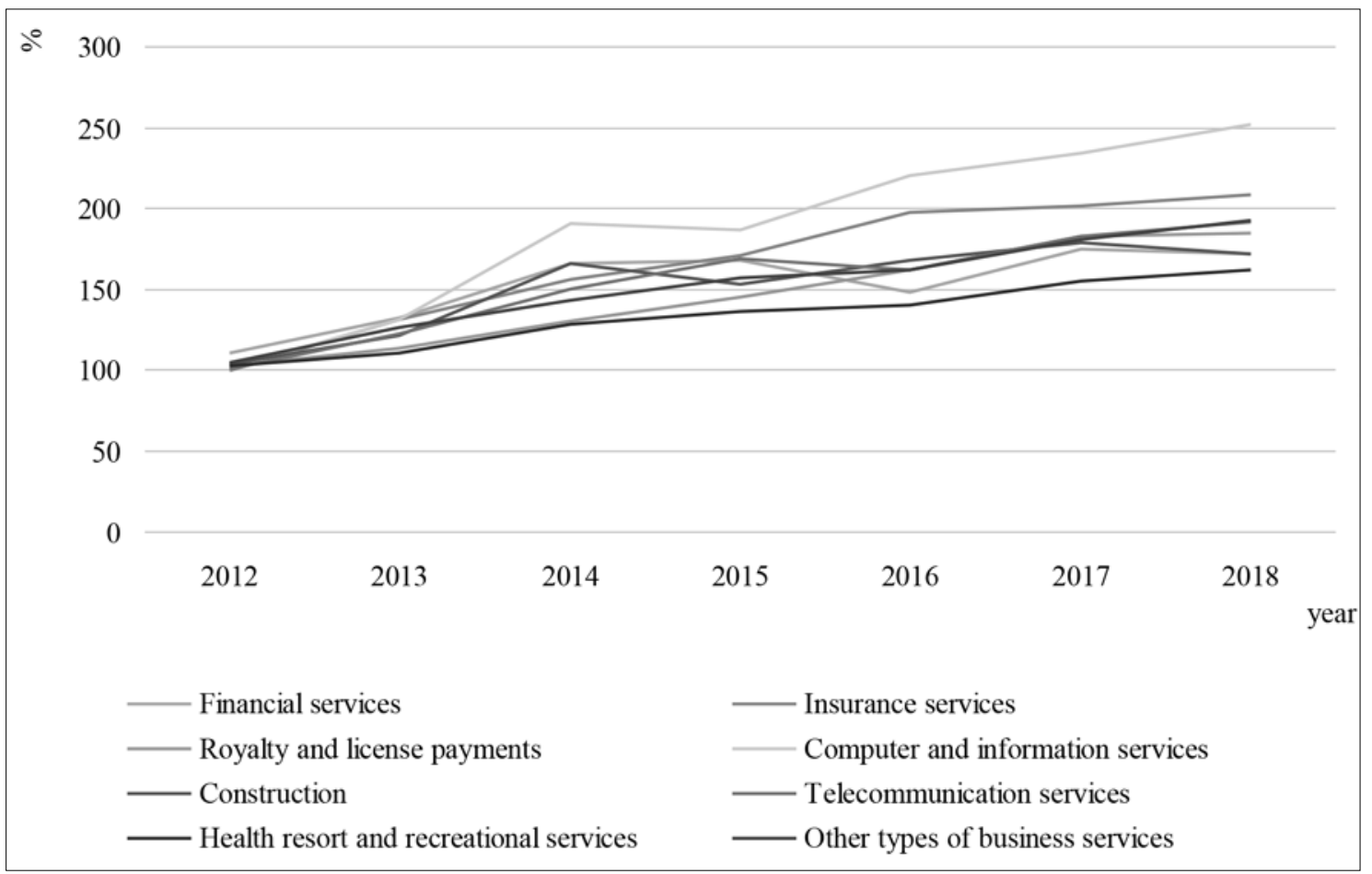

Fig. 5. Export growth of other commercial services 2012-2018, INDEX $2012=100$.

Source: Developed by the authors according to the sources (OECD Science, Technology and Industry Scoreboard, 2018) 
The average annual growth of exports of computer and information services amounted to $14 \%$, insurance services - $11 \%$, telecommunications services - $11 \%$. The share of other commercial services in the global export of services is $54 \%$, including some $60 \%$ or more in the developed countries (The Global Information Technology Report). More than $95 \%$ of revenues under this heading come from various types of business services, $5 \%$ are personal, recreational and cultural services.

In line with the methodology of the sixth edition of the IMF Guidelines on Balance of Payments and International Investment Position, the group of other business services is represented by intermediary services, services for operating leasing and other business, professional and technical services. Fig. 6. shows main exporters of other business services in 2018.

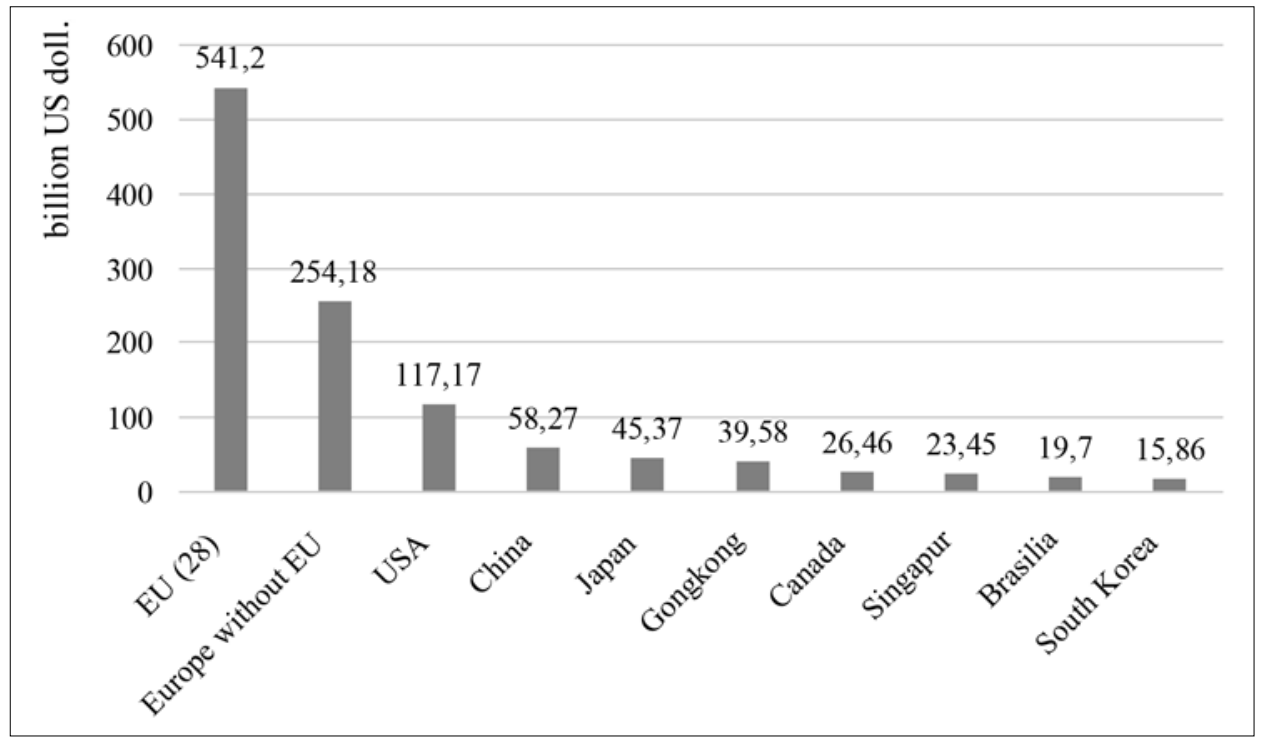

Fig. 6. Volume of exports of other business services in 2018, billion US dollars

Source: Developed by the authors according to the source (World trade statistical review, 2018)

Fig. 7. shows main exporters of other business services in 2018.

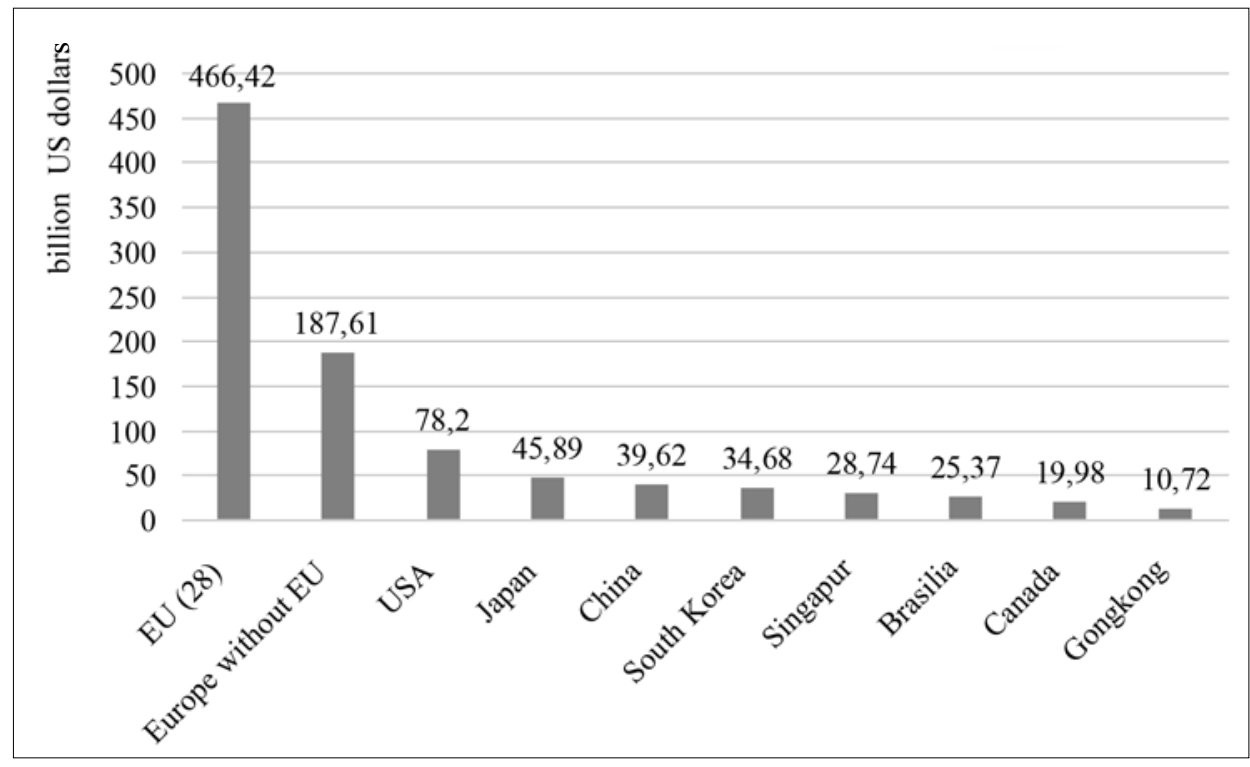

Fig. 7. Volume of import of other business services in 2018, mln. dollars 
As we see from the figure, the main suppliers and consumers of other business services are the countries of Europe, EU and, in particular, the United States. Among the most dynamic articles of international trade one can distinguish business services, primarily information, consulting and other high-tech services.

The distribution of international supply of services from existing supply methods is a complex task, since production, distribution, marketing, sales, and delivery of services can often be carried out in many ways, as described above. Example: a specialist working in an audit firm goes abroad to establish business contacts with a potential client (the method of "presence of individuals" in the initial absence of an economic transaction), the client's consultation process, in case of establishment of business relations, may also be carried out online in the future (the method of "cross-border provision"), and the situation may arise when the client comes to get advice itself (the method of "consuming abroad") (Handbook of Statistics, 2018). The stable business contacts with a client abroad can lead to the establishment of representation abroad by a firm (the "business presence" method).

In international trade, EU countries are dominating in renderind other business services - more than $50 \%$ of world exports and imports of services. The business services show a qualitatively new level in their development, have significantly increased the level and quality of customer service and play an important role today in the effective development of the economy of Western countries. The interest is due not only to the quantitative characteristics, but also to the qualitative characteristics of this category of services, which is also relevant for the analysis of the development of these services in the EU.

In the countries of Western Europe, the share of employed in the service sector is more than $58.5-74 \%$ of the total number of employees. In the EU countries, the share of services in GDP and employment is $65-75 \%$ and $65 \%$, respectively. The service sector has $50 \%$ of foreign direct investment in the world. The group of leading services in the EU countries is represented by a group of knowledge-intensive industries (telecommunication services, financial services, insurance services, business services of scientific content, education, health care, etc.). (Eurostat, 2018).

Scientific and technological progress, namely, information technology and computer technology, time and geographical boundaries, which are reduced or eliminated in the course of business activity, force the services to operate in a new way.

The export share of high-tech services in the EU countries is $50 \%$ of total exports. The leading export countries for science-intensive services are Denmark, Ireland, Great Britain, and Luxembourg (more than 60\%). The rate of growth of the export share of high-tech services in the EU countries is on average $1.5 \%$. This figure is $10 \%$ in countries such as Finland, Hungary, and Malta ((European Innovation Scoreboard, 2018).

New types of services are developing, including, as a result of their cheapening and expansion of an access by means of information technologies, which positively affects their quality, it becomes possible to process the service more individually, services become not only more diverse and more accessible, but also the convenience of consumption improves, and eventually utility per unit increases.

In most European Union countries, consulting services (marketing, advertising, leasing, engineering, construction and architectural services, accounting services, audit services, etc.) and non-technical types of business services (selection services staff, public relations, etc.) take the leading place in the growth rate of the European Union. Among the EU countries, the leaders in providing business services are: Great Britain, Germany, the Netherlands, Cyprus, France, and Luxembourg. Among the EU countries, the leaders in consumption business services are: Great Britain, Germany, Netherlands, Cyprus, France, Czech Republic, Austria, and Finland. Business services bring the greatest contribution to the category of intellectual services, in the EU countries this figure is $11 \%$ (Fig. 8). 


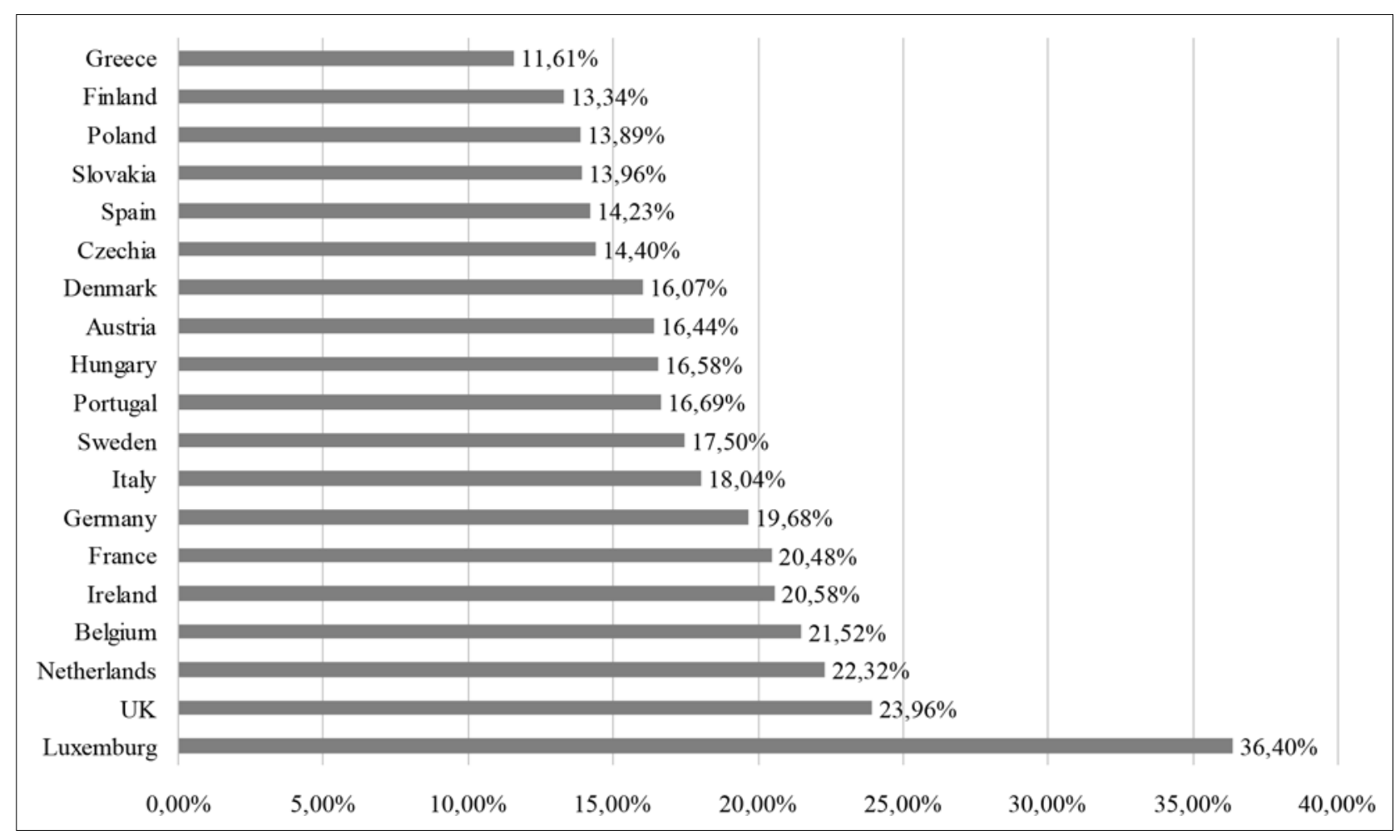

Fig. 8. The share of intellectual services in the gross value added of the EU countries, in \%

Source: Developed by the authors according to the source (European Innovation Scoreboard, 2018).

The development of the sector of intellectual services indicates the level of development of the economy. In the course of analysis it was found that the well-being of a given country is also related to the sector of intellectual services. The average indicator of the share of intellectual services in gross value added by EU countries is $20 \%$.

The dynamic growth of the volume of research and development is also characteristic of the services sector, while it extends not only to information and telecommunication services, but also to other types (Fig. 9).

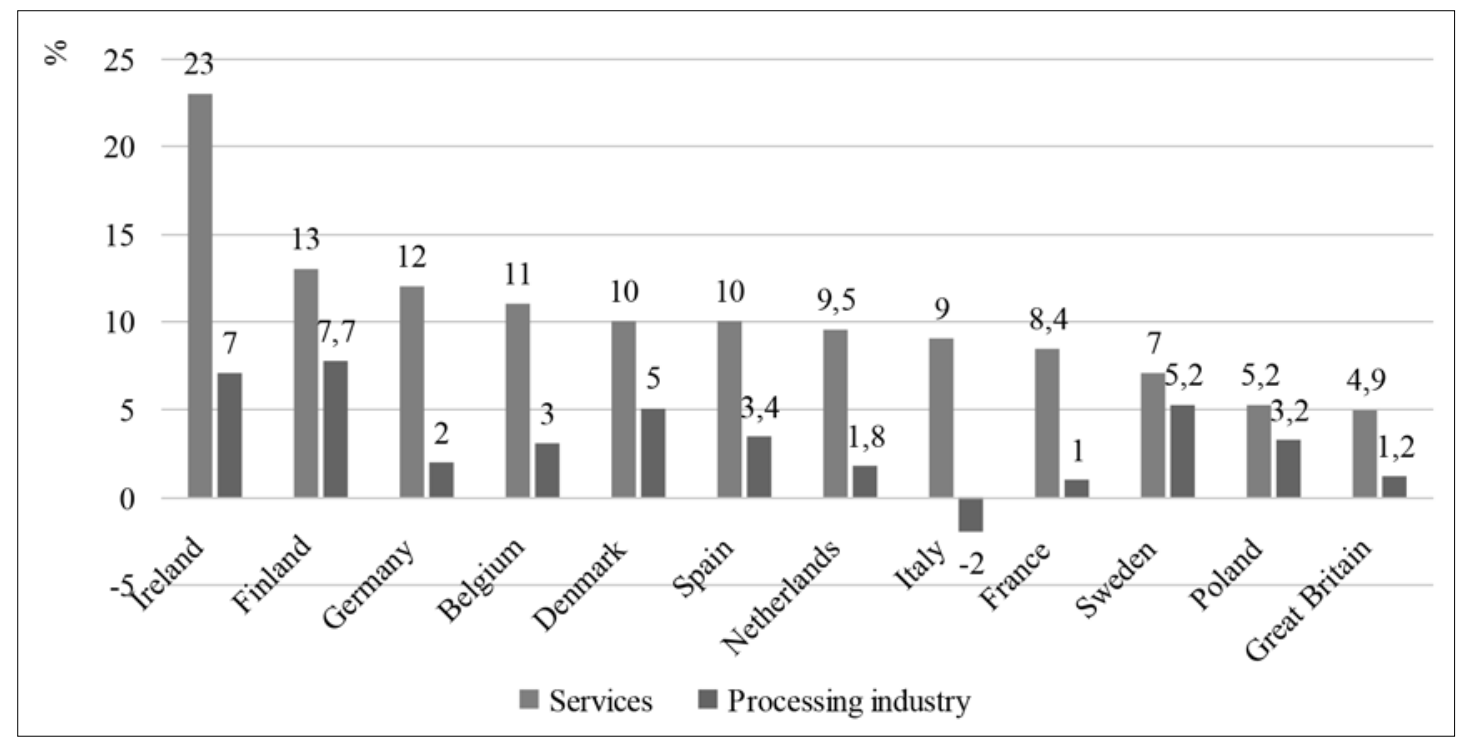

Fig. 9. The average annual growth rate of research and development costs in the service sector and manufacturing industry of the EU countries for the period 2010-2018, \%

Source: Developed by the authors according to the source (European Innovation Scoreboard, 2018). 
There is a significant growth of innovation activity in the services sector. So, the share of such firms in the field of business services has already reached 50\% in Estonia and Germany in the period of 2010-2018 (Fig. 10).

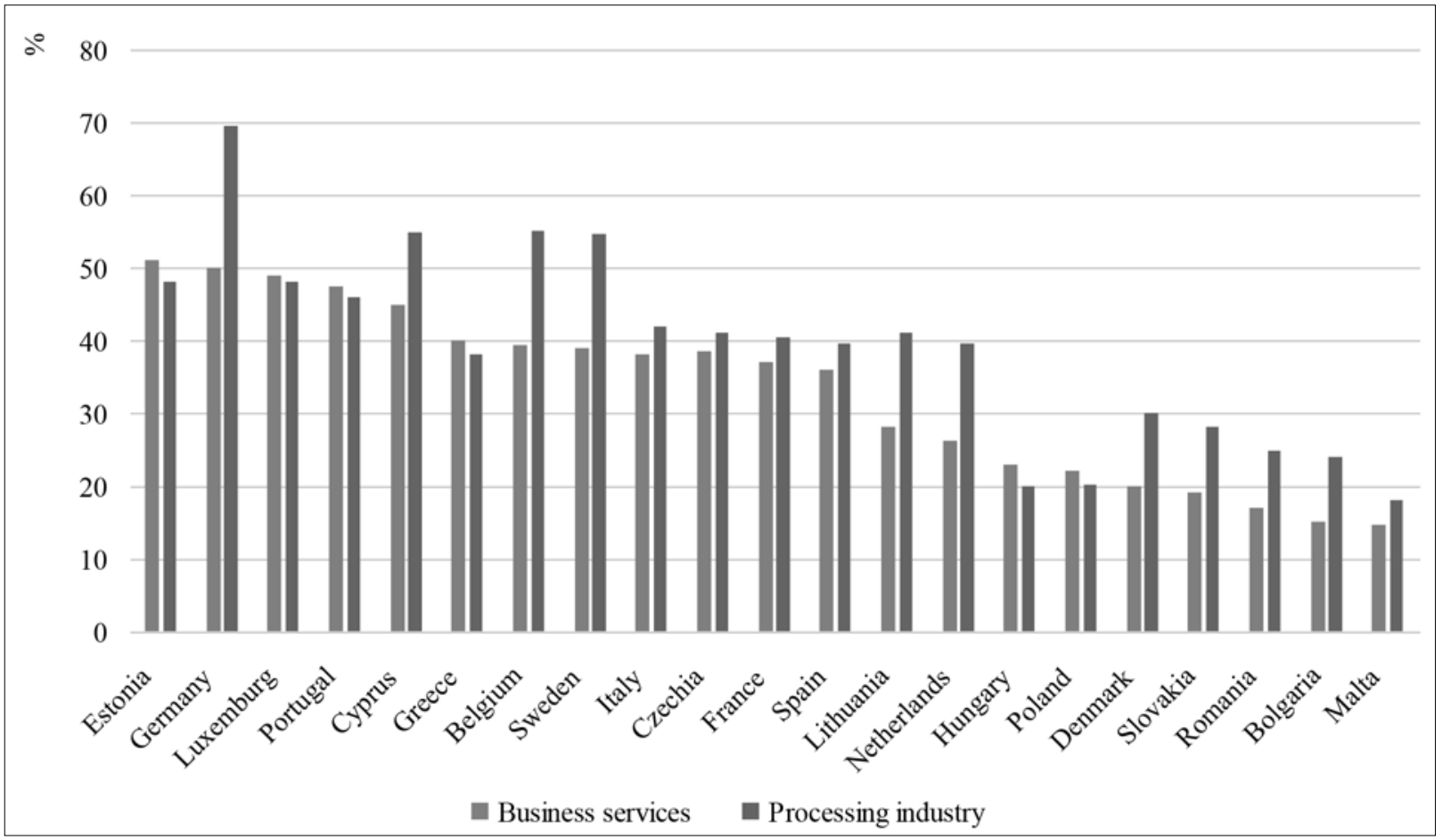

Fig. 10. The share of innovative active firms in the sector of business services and in processing industry in the EU countries for the period $2010-2018, \%$

Source: Developed by the authors according to the source (European Innovation Scoreboard, 2018).

In general, services of an informational nature (financial services, business services) show a higher level of innovation than services based on the use of tangible objects (transport, wholesale and retail trade).

\section{Discussion}

The predominance of non-technology-related innovation services will be explained by the fact that they have more instrumental nature in the service sector. The share of service sector in total business expenses for innovation activity is almost $30 \%$ in all EU countries, but the expenses of service firms for innovation are usually less than industrial ones, even with the adjustment for the size of companies (service companies on average are smaller than industrial ones).

The efforts of many EU countries are aimed at active working on development of approaches to the development of services innovation.

The prerequisites for the creation of a pan-European strategy for innovation and intellectual sefaty are (Koenig, 2016):

- growth of high-tech (intellectual) services;

- growth of innovation activity in the service sector;

- the predominance of innovations not related to technologies.

EU countries are keen to have the services market as transparent as possible and the end user has access to information about innovation-active service providers.

The EU expert group indicated the following measures aimed at solving the following tasks: 
- European innovation platform for high-tech services;

- European Institute of Innovation in the service sector;

- network of information exchange on innovative services;

- initiative to support risky innovative services projects.

The active policy in this direction is only beginning to develop. An important area of development is the improvement of statistics, as well as an effective system of indicators and data collection that will make the scope of services more transparent.

An example of a statistical base can be the European option, which includes (Eurostat, 2018):

- trends in innovation in Europe (The Trend Chart on Innovation in Europe) - dissemination of successful innovation experience;

- European Innovation Scoreboad - annual data on the state of science, technology, innovative activity of companies and the innovation environment, including international comparisons with other countries;

- The Innobarometer is a special study of individual innovation policy parameters, including the company's attitude to change, data on the volume of costs of innovation and the impact of domestic and foreign markets on the efficiency of innovations;

- the activities of the electronic information service on R\&D in innovation policy - CORDIS, which provides information on the possibility of using the results of project work.

According to the annual monitoring of The Innobarometer, the EU countries are subdivided into the following fairly stable groups (Table. 2).

Table 2. EU member states on the level of innovation development

\begin{tabular}{|c|c|}
\hline $\begin{array}{c}\text { Groups of countries according } \\
\text { to the level of development of innovations }\end{array}$ & The countries of Europe \\
\hline Innovative favorites & Great Britain, Denmark, Germany, Finland, and Sweden \\
\hline Those that catching up favorites & Austria, Belgium, Ireland, Luxembourg, the Netherlands, and France \\
\hline Medium innovators & Greece, Spain, Italy, Cyprus, Portugal, Slovenia, Czech Republic, and Estonia \\
\hline Catching up countries & Bulgaria, Hungary, Latvia, Lithuania, Malta, Poland, Romania, and Slovakia \\
\hline
\end{tabular}

Source: Designed by the authors

According to the global index of innovation, which is formed on the basis of several indicators, the following leading countries can be distinguished:

Innovative environment within businesses (R\&D, FDI and technology transfer costs) - Sweden.

Innovative ecosystems (UNDP. Human Development Report, 2018):

- the state of cluster development is Italy, Sweden, Finland, and Great Britain.

- innovation culture - Great Britain, Germany, Belgium, and Finland.

- cooperation between universities and various branches - Finland, Sweden, Denmark, and Great Britain.

Openness to intranet and foreign competition (indicator of trade barriers, average weighted rate of import customs tariff, intensity of intra-national competition) - Denmark and the Netherlands.

- The report of the European Commission's expert group describes services that have a significant impact on the business environment and may potentially change the direction of innovation development.

- The so-called "transforming services" include:

- services related to the creation of networks, the establishment of business contacts that provide interaction between consumers, 
- companies and participants in the production-sale chain, and also improve the distribution of goods and information exchange.

- municipal and infrastructure services (services of telecommunication, power companies, garbage collection companies, etc.).

- Business services based on a large amount of professional knowledge, the production of which is carried out through close interaction with customers, in order to improve their technologies, organizational processes and models, and exchange knowledge and experience between different sectors (Gruszczak, 2016).

Focusing on these types of services is in line with the principle of enhancing the orientation of the EU's innovation policy to improve the value chain and the conditions for the development of universities, research institutions, private companies, government agencies and consumers (Davidavičienè, et al., 2019).

Let's consider the main models of observance of innovation safety in services in EU countries:

1. The classic scheme of research and development (R\&D), which can be found mainly in large high-tech companies.

2. The replication of professional solutions is most often traced in the production of intellectual services. Specialists of such companies, due to their high qualifications, often develop unique client-focused solutions. Such innovative practices can be disseminated through networks, associations and other professional communities. Many consulting companies and representatives of other sectors (such as advertising and design services) follow this model (Kirchner, et al., 2015). The most important task for them is the search and adaptation of innovations created by professionals in practice, and knowledge management is aimed at solving this particular problem.

The neo-industrial model occupies an intermediate position between the two previous ones. Together with innovations generated by specialized departments for $R \& D$ or innovation, there are spontaneous innovations that are born in solving current practical problems.

The purposeful innovation strategy is found in large service companies. The innovation process is carried out in the form of projects, which are usually implemented by temporary teams recruited from different divisions. They work strictly according to project management rules, often under the strict guidance of marketing departments (Labanauskis, et al., 2018).

The entrepreneurial type of organization of the innovation process is characteristic for start-up companies, which offer more or less radical innovations of both technological and managerial nature. Similarly, the small, but fast-growing firms and companies that make online services, etc., are developing in many sectors of service market. But usually they adhere to this trend for a short time and quickly switch to another type of innovative behavior.

"Amateurish" (unprofessional) type of innovation management is found in small companies that make low-tech services related to the maintenance of material objects (eg, cleaning or catering). These are classical non-client sectors that borrow most of the innovations from other sectors (for example, from industry), although they can themselves develop innovations in response to changes in legislation and demand. The personnel and managers of such companies can also generate innovation, but usually of an improving nature.

The network type covers a set of companies that operate jointly and have common standards and procedures. There may be a dominant company in such a network that is characterized by the spread of innovations, for example, in e-commerce, from which customers require standard trading conditions. In a number of service industries that make fast food, provide hotel services and some professional services, innovations are distributed through franchising network. It has been found that innovative organizations in many EU countries apply the following practices or their combination (Hollis, 2010). 
The internal and external R\&D, patenting, and registration of prototypes and copyright) are new for market innovations (this practice implies product innovations and technological aspects of innovation that are new for the market.

Marketing innovations (practice implies the introduction of new innovations for the firm (not for the market) and bearing costs for marketing associated with them).

The modernization of processes (practice refers to process innovations, the purchase of machinery and equipment, other knowledge, training and retraining of personnel). This factor reflects the combination of technological and non-technological components. The iinnovative activities are extended (practice related to non-technological aspects of innovation). The usage of advanced management techniques, improvement of organizational structures, and new marketing strategies (Balzacq, 2010).

The discrepancy between national models is observed mostly relative to innovation that are new for the market, and the similarity is observed within the framework of modernization and advanced innovations. One way or another, countries in one form or another practice new innovations for the market. This option is related to the generation of own technologies, which proves the high factor load that comes from internal research and development, as well as intellectual property rights.

\section{Conclusions}

The significance of the service sector is related not only to the predominance of the economy structure, but also to the formation of key factors in economic growth in its sectors. Trade in services is one of the most dynamic sectors of international trade. The group of other commercial services is allocated more dynamically. The share of other types of business services in trade in commercial services is $48 \%$.

The main suppliers and consumers of other business services are the countries of Europe, EU and, in particular, the United States. The fastest growth demonstrates the trade in computer and information services, insurance services, telecommunications, and other business services.

The development of the world market for business intelligence services takes place under conditions of intense competition and under the influence of non-price factors. The leading services group in the EU includes telecommunications, credit-and-financial services and insurance services, and business services. In most EU countries, services in the field of marketing, advertising, leasing, engineering and architectural services, accounting services, audit services, as well as non-technical types of business services are at the forefront of growth.

The business services bring the greatest contribution to the category of intellectual services (an average of $11 \%$ ). The average indicator of the share of intellectual services in gross value added by EU countries is $20 \%$.

There is a high innovation activity in the service sector in the EU countries. In general, services of an informational nature (financial services, business services) show a higher level of innovation. The predominance of non-technology-related innovation services will be explained by the fact that they have more instrumental nature in the service sector.

The category of services that affect the business environment and potentially can change the direction of innovation development in EU includes so-called business services based on a large amount of professional knowledge, the production of which is carried out through close interaction with customers. The focusing attention on these types of services is in line with the principle that means strengthening the orientation of EU innovation policy and safety. 


\section{References}

Abrhám, J., Lžicar, P. (2018). Risk management in the sustainable development: analysis of a selected key industry Journal of Security and Sustainability Issues 8(2): 171-180. https://doi.org/10.9770/jssi.2018.8.2(5)

Balzacq, T. (2010). Securitization Theory: How Security Problems Emerge and Dissolve. Abingdon: Routledge. https://doi. org/10.4324/9780203868508

Bonditti, P., Bigo, D., \& Gros, F. (2017). Foucault and the Modern International: Silences and Legacies for the Study of World Politics. Berlin: Springer https://doi.org/10.1057/978-1-137-56153-4

Chaffey, D., \& Ellis-Chadwick, F. (2012). Digital Marketing: Strategy, Implementation and Practice (5th ed.). Pearson Education. ISBN-13: 978-0273746102 ISBN-10: 0273746103

Davidavičienè, V.; Raudeliūnienè, J.; Tvaronavičienė, M.; Kaušinis, J. (2019). The importance of security aspects in consumer preferences in electronic environment, Journal of Security and Sustainability Issues 8(3): 399-411. http://doi.org/10.9770/jssi.2019.8.3(9)

Dźwigoł, H., Dźwigoł-Barosz, M., Zhyvko, Z., Miśkiewicz, R., Pushak, H. (2019). Evaluation of the energy security as a component of national security of the country, Journal of Security and Sustainability Issues 8(3): 307-317. http://doi.org/10.9770/jssi.2019.8.3(2)

European Innovation Scoreboard (2018). Available on the Internet: http://ec.europa.eu/growth/content/european-innovation-scoreboard-2018-europe-must-deepen-its-innovation-edge_en

Eurostat, (2018). Unmet health care needs statistics. Available on the Internet: https://ec.europa.eu/eurostat/statistics-explained/index. php?title=Unmet_health_care_needs_statistics

Girdzijauskaite, E., Radzeviciene, A., Jakubavicius, A. (2019). Impact of international branch campus KPIs on the university competitiveness: FARE method. Insights into Regional Development, 1(2), 171-180. https://doi.org/10.9770/ird.2019.1.2(7)

Global Economic Prospects (2019). Available on the Internet: http://www.worldbank.org/en/publication/global-economic-prospects

Gruszczak, A. (2016). Intelligence Security in the European Union: Building a Strategic Intelligence Community. Berlin: Springer. https://doi.org/10.1057/978-1-137-45512-3

Drobyazko S. (2017). Formation of competitive positions as providing of economic security of insurance companies. International scientific journal “Internauka”. Series: “Economic Sciences”, 2017, №2. URL: https://doi.org/10.25313/2520-2294-2017-2-4784

Drobyazko S., Hryhoruk I., Pavlova H., Volchanska V., Sergiychuk S. (2019). Entrepreneurship innovation model for telecommunications enterprises. Journal of Entrepreneurship Education, Volume 22, Issue 2, 2019. URL: https://www.abacademies.org/articles/ entrepreneurship-innovation-model-for-telecommunications-enterprises-8097.html

Handbook of Statistics (2018). UNCTAD Available on the Internet: https://unctad.org/en/PublicationsLibrary/tdstat43_en.pdf

Hollis, S. (2010). The necessity of protection: Transgovernmental networks and EU security governance. Cooperation and Conflict, 45(3), 312-330. https://doi.org/10.1177/0010836710378071

Hunt, Sh. D.A. (2000). General Theory of Competition: Resources, Competences, Productivity, Economic Growth. Sage Publications: Thousand Oaks https://www.academia.edu/2731791/A_General_Theory_of_Competition_Resources_Competences_Productivity_Economic_Growth_by_Shelby_D._Hunt

International Trade Statistics Yearbook. Available on the Internet: https://www.un-ilibrary.org/international-trade-and-finance/international-trade-statistics-yearbook-ser-g_e9aba95b-en

Kirchner, E., Fanoulis, E., \& Dorussen, H. (2015). Civil security in the EU: national persistence versus EU ambitions? European Security, 24(2), 287-303. https://doi.org/10.1080/09662839.2014.968133

Kirshner, J. (2013). Globalization and National Security. London: Routledge. ISBN-13: 978-0415955119 ISBN-10: 0415955114

Koenig, N. (2016). EU Security Policy and Crisis Management: A Quest for Coherence. New York: Routledge. ISBN: 978-1138961340

Labanauskis, R., Kasparavičiūtė, A., Davidavičienė, V., Deltuvienė D. (2018). Towards Quality Assurance of the Study Process Using the Multi-Criteria Decision-Making Method, Entrepreneurship and Sustainability Issues 6(2): 799-819. http://doi.org/10.9770/ jesi.2018.6.2(22)

Leese, M., \& Wittendorp, S. (2017). Security/Mobility: Politics of Movement. Manchester: Manchester University Press. 
Makedon, V. (2018). Strategic challenges and trends of development of oil-gas transnational corporations USA. Visnyk of Dnipro University. Ser. World Economy and International Economic Relations, 26(10), 51-63. https://doi.org/10.15421/181805

OECD Science, Technology and Industry Scoreboard (2018). Available on the Internet: https://www.oecd.org/sti/scoreboard.htm

Rogers, E.M. (2003). Diffusion of Innovation, 5th ed. N.Y.: Simon \& Schuster, p. 567.

Sagiyeva, R,, Zhuparova, A., Ruzanov, R., Doszhan, R., Askerov, A. (2018). Intellectual input of development by knowledge-based economy: problems of measuring in countries with developing markets. Entrepreneurship and Sustainability Issues, 6(2), 711-728. http://doi.org/10.9770/jesi.2018.6.2(17)

Senan, N.A. (2018). Developmental review program impact on enhancing the effectiveness of «Teaching and Learning» in accounting program: a case study in a Saudi University. Entrepreneurship and Sustainability Issues, 6(2), 1001-1017. https://oi.org/10.9770/ jesi.2018.6.2(35)

Solomon, M. R., Bamossy, G., Askegaard, S., \& Hoog, M. K. (2016). Consumer Behaviour: a European Perspective (6th ed.). Pearson. https://books.mec.biz/tmp/books/NXHQRTHBQ2L87NIU6YVN.pdf

Standler, C. (2014). Mapping out the institutional geography of external security in the EU. European Security, 24(3), 402-419. https:// doi.org/10.1080/09662839.2015.1028187

The Global Information Technology Report. Available on the Internet: http://www3.weforum.org/docs/GITR2016/WEF_GITR_Full_ Report.pdf

Thompson, N., Ravindran, R., \& Nicosia, S. (2015). Government data does not mean data governance: Lessons learned from a public sector application audit. Government Information Quarterly, 32(3), 316-322. http://doi.org/10.1016/j.giq.2015.05.001

UNDP. Human Development Report, (2018): Available on the Internet: http://hdr.undp.org/en/2018-update

Vo, L., Van, Le, H. T., Le, D. V., Phung, M. T., Wang, Y.H., \& Yang, F.J. (2017). Customer satisfaction and corporate investment policies. Journal of Business Economics and Management, 18(2), 202-223. https://doi.org/10.3846/16111699.2017.1280845

World trade statistical review, (2018). World Trade Organization. Available on the Internet: https://www.wto.org/english/res_e/statis_e/ wts2018_e/wts2018_e.pdf

Svitlana FILYPPOVA, Doctor of Economics, Professor, Director of the Educational and research institute of Economics, Economics and Information Technologies, Odessa National Polytechnic University

ORCID ID: orcid.org/0000-0003-2245-3599

Valery OKULICH-KAZARIN, Dr. hab, MBA, Pedagogical University of Cracow

ORCID ID: orcid.org/0000-0001-6486-1369

Olha KIBIK, Doctor of Economics, Professor, Head of the Department of National Economy, National University "Odessa Law Academy"

ORCID ID: orcid.org/0000-0002-2179-8483

Grygoriy SHAMBOROVSKYI, PhD of Economics, Associate Professor, Ivan Franko National University of Lviv ORCID ID: orcid.org/0000-0003-2284-0542

Svitlana CHERKASOVA, PhD of Economics, Associate Professor, Odessa National Polytechnic University ORCID ID: orcid.org/0000-0002-0563-9634

This work is licensed under the Creative Commons Attribution International License (CC BY). $\mathrm{http}: / /$ creativecommons.org/licenses/by/4.0/ 